\title{
Pengembangan Sistem Informasi Manajemen Skrining Case Manager RSUP Persahabatan Jakarta
}

\author{
Muhammad Chandra ${ }^{1}$, Enie Novieastari ${ }^{2}$, Sri Purwaningsih ${ }^{3}$ \\ 1. Fakultas Ilmu Keperawatan Universitas Indonesia, email: nersmchandra@gmail.com \\ 2. Fakultas Ilmu Keperawatan Universitas Indonesia \\ 3. RSUP Persahabatan Jakarta.
}

\begin{abstract}
Abstrak
Pendampingan pelayanan oleh case manager diawali dengan skrining pasien, namun metode skrining dan pelaporan hasil skrining secara manual cendrung kurang efektif dan kurang efisien. Inovasi ini bertujauan untuk mengembangkan sistem skrining yang lebih efektif dan efisien melalui yaitu skrining berbasis sistem informasi manajemen. Metode yang digunakan adalah prototyping model. Hasil inovasi ini adalah sebuah prototipe sistem informasi manajemen skrining case manager berbasis web dan android. Aplikasi ini digunakan oleh perawat yang melakukan skrining dan case manager yang melakukan verifikasi hasil skrining. Dengan sistem update yang real time, aplikasi ini sangat bermanfaat untuk meningkatkan efektifitas dan efisiensi skrining dan pelaporan hasil skrining case manager di rumah sakit. Rumah sakit diharapkan dapat menerapkan sistem ini untuk menigkatkan efektifitas dan efisiensi layanan khususnya case manager.
\end{abstract}

Kata kunci: case manager, prototyping model, sistem informasi manajemen

\section{Development of Case Manager Screening Management Information System at RSUP Persahabatan Jakarta}

\begin{abstract}
Service assistance by the case manager begins with screening patients, but the method of screening and reporting the results of manual screening tends to be less effective and less efficient. This innovation aims to develop a more effective and efficient screening system through management information system-based screening. The method used is the prototyping model. This result is a prototype of a webbased and android case manager screening management information system. This application is used by nurses who conduct screening and case managers who verify the results of screening. With real time system updates, this application is very useful for improving the effectiveness and efficiency of screening and reporting the results of case manager screening at the hospital. Hospitals are expected to implement this system to improve the effectiveness and efficiency of special case manager services.
\end{abstract}

Keywords : case manager, prototyping model, management information system

\section{Pendahuluan}

Perkembangan IPTEK yang cukup pesat saat ini menuntut semua pihak untuk terus berinovasi demi peningkatan efektifitas dan efisiensi dalam pelayanan, termasuk pelayanan rumah sakit. Salah satu upaya yang dapat dilakukan yaitu pengembangan dan pemanfaatan sistem informasi manajemen berbasis teknologi sistem informasi. Hal ini sesuai dengan PMK No 82 tahun 2013 tentang SIMRS yang menyatakan bahwa pembentukan SIMRS ditujukan untuk efisiensi dan efektifitas penyelenggaraan rumah sakit (Menkes RI, 2013). Peraturan lain juga menegaskan bahwa setiap rumah sakit wajib melakukan pencatatan dan pelaporan semua kegiatan penyelenggaraan rumah sakit dalam bentuk sistem informasi manajemen rumah sakit (DPR RI dan Presiden, 2009).

Sistem informasi manajemen memebrikan berbagai keutungan bagi rumah sakit. Sistem yang terkomputerisasi memiliki keunggulan dari segi efektifitas administrasi dan manajemen pelayanan dibandingkan dengan metode manual (Malliarou, M. Zyga, 2009). Sejalan dengan Shaqiri (2015) yang menyatakan bahwa sistem informasi manajemen meningkatkan efisiensi dibandingkan dengan sistem lama, 
serta penyampaian informasi yang cepat dengan jangkauan yang luas (Berishashaqiri, 2015).

Rumah sakit sebagai salah satu institusi pelayanan kesehatan dituntut untuk memberikan pelayanan yang paripurna dan berfokus pada pasien. Sesuai dengan undang-undang RI No. 38 tahun 2014 tentang keperawatan, pelayanan kesehatan paripurna meliputi promotif, preventif, kuratif dan rehabilitatif (DPR RI dan Presiden, 2014). Patient-centered care merupakan konsep dan standar asuhan yang menggambarkan pengorganisasian sistem asuhan terhadap pasien, dengan tujuan untuk meningkatkan kualitas asuhan (Ben Natan and Hocman, 2017). Hal ini sesuai dengan standar yang dikeluarkan oleh KARS dalam SNARS edisi 1, bahwa proses pelayanan berfokus pasien menjadi standar yang harus diterapkan oleh institusi kesehatan dalam hal ini rumah sakit, melalui peranan case manager(KARS, 2017). Hal ini juga sesuai dengan JCI yang menyebutkan salah satu cara intergrasi dan koordinasi asuhan pasien melalui peran seorang case manager(JCI, 2017).

Peran case managersecara garis besar yaitu sebagai seorang koordinator, fasilitator, pemberi advokasi, serta edukator (Sutoto \& Lumenta, 2017). Dalam menjalankan manajemen pelayanan pasien, case manager mempunyai peran minimal yaitu: (a) memfasilitasi pemenuhan kebutuhan asuhan pasien;

mengoptimalkan terlaksananya pelayanan berfokus pada pasien; (c) mengoptimalkan proses reimbursemen; dan dengan fungsi sebagai berikut: (a) asesmen untuk manajemen pelayanan pasien;

perencanaan untuk manajemen pelayanan pasien; (c) komunikasi dan koordinasi; (d) edukasi dan advokasi; (e) kendali mutu dan biaya pelayanan pasien(KARS, 2017).

Pelayanan case manager diawali dengan skrining kebutuhan pasien akan pendampingan case manager. Hal ini sesuai dengan KARS (2017) dan CMSA (2016).
Skrining dilakukan oleh professional dalam manajemen kasus (CMSA, 2016) yang bertugas memberikan pelayanan termasuk perawat. Skrining mengguakan kriteriakriteria tertentu untuk menentukan apakah pasien termasuk dalam kategori yang membutuhkan pendampingan case manager. Kriteria tersebut antara lain seperti: kasus kompleks, penyakit kronis, kasus terminal; masalah finansial; kurangnya dukungan sosial dan lain sebagainya (CMSA, 2016).

RSUP Persahabatan mendukung terwujudnya pelayan berfokus pada pasien dengan menetapkan 12 perawat sebagai case manager/ manajer pelayanan pasien (MPP). beserta uraian tugasnya. Proses manajemen pelayanan pasien tidak dapat berjalan optimal tanpa dukungan dari semua stakeholder yang ada. Namun, berdasarkan laporan kinerja manager pelayanan pasien bulan Mei hingga Juli 2018 ditemukan data antara lain: belum optimalnya skrining pasien oleh kepala ruangan dan ketua tim. Skrining yang dilakukan masing menggunakan form manual/ berbasis kertas. Hal ini cenderung kurang efektif dan kurang efisien baik dari segi waktu skrining, pelaporan hasil skrining maupun penggunaan kertas yang makin bertambah. Hasil identikasi awal menunjukakan masih ada pelaporan hasil skrining yang menunggu datangnya case manager ke ruangan. Bersasarkan survei yang diikuti oleh 313 perawat ditemukan bahwa $77,3 \%$ perawat menyatkan pentingnya skrining untuk kebutuhan pasien akancase manager, 57,8\% menyatakan form skrining menambah banyaknya form yang harus diisi, 54\% pelaporan hasil skrining menunggu case manager datang ke ruangan, $42 \%$ metode pelaporan hasil srining saat ini kurang efektif dan kurang efisien, 71,2 \% menyatakan perlunya metode yang lebih efektif dan efisien.

Berdasarkan data diatas, maka diperlukan adanya suatu metode yang lebih efektif dan efisien dalam hal skrining pasien akan kebutuhan case manager sehingga dapat meningkatkan manajemen pelayanan 
pasien menjadi lebih baik.

\section{Metode}

Metodologi pengembangan sistem yang digunakan yaitu prototyping model. Prototipe dapat digunakan untuk membangun suatu sistem dengan uji coba yang cepat dan mudah dievaluasi (Laudon and Laudon, 2014). Identifikasi masalah yang mendasari pembuatan sistem dilakukan analisis PIECES terhadap sistem lama yang masih digunakan. Analisis PIECES yang dilakukan meliputi performance, information, economy, control, efficiency, service. Pemilihan metode ini untuk menggali kebutuhan aplikasi sistem informasi yang akan dikembangkan.

\section{Hasil Penelitian}

1. Analisis Sistem dengan Kerangka PIECES

\section{a. Performance}

Saat ini penggunaan sistem skrining case manager yang ada di RSUP Persahabatan masih menggunakan form manual/ paper based. Form skrining di ruang rawat inap diisi oleh kepala ruangan tatu ketua tim, namun untuk IGD skrining dilakukan langsung oleh case manager.

Metode skrining manual ini cenderung kurang efektif dan kurang efisien. Form manual menambah tingginya penggunaan kertas di rumah sakit, serta metode pelaporan hasil skrining yang kurang efisiensi waktu. Sehingga masih terdapat pelaporan hasil skrining yang menunggu datangnya case manager ke ruangan.

\section{b. Information}

Case manager memerlukan informasi yang cepat dan akurat untuk menentukan kebutuhan pasien akan pendampingan case manager. Informasi tersebut pertama diperoleh dari hasil skrining yang dilakukan oleh kepala ruangan dan ketua tim. Namun dalam beberapa kasus, pelaporan hasil skrining kurang efektif dan kurang efisien waktu, kepala ruanagn atau katim membutuhkan waktu utuk pelaporan dan beberapa situasi bahkan menunggu datangnya case manager ke ruangan baru dilaporkan.

\section{c. Economy}

Dalam segi ekonomi jika sistem skrining sudah berjalan secara efektif dan efisien maka secara langsung/ tidak langsung akan berdampak pada pelayanan pasien. penggunaan atk (kertas, pena dll) yang berkurang, waktu pelaporan akan lebih cepat dengan adanya kejelasan informasi. Yang terjadi saat ini adalah penggunaan form manual yang kurang efektif dan efisien, baik dari segi waktu maupun ekonomi.

\section{d. Control}

Sistem informasi yang di gunakan di RSUP Persahabatan dikendalikan oleh Unit Manajemen Sistem Informasi. Sistem keamanan yang dimilliki yaitu pneggunaan user namedan passworduntuk masingmasinguser. Dengan demikian tidak semua orang dapat masuk/ mengakses sistem informasi tersebut. Namun terkait skrining case manager belum ada form elektronik/ masih 
manual mengguanakan kertas sehingga tidak ada sistem keamanan yang dikelola oleh unit manajemen sistem informasi rumah sakit.

e. Efficiency

Sistem skrining case manager yang masih manual seperti saat ini berpengaruh tehadap efisiensi waktu peayanan. Pelaporan hasil skrining yang terlambat dapat menghambat proses pendampingan pasien oleh case manajer. Sehingga, tidak jarang terjadi pelaporan menunggu datangnya case menager ke ruangan.

\section{f. Services}

Layanan yang digunakan saat ini masih mengunakan sistem manual/ mnggunakan kertas. Dengan demikian, proses pelaporan hasil skrining tidak real time, namun harus menghubungi case manager melalui telepon untuk melaporkan hasil skrining pasien yang membutuhkan pendampingan case manager.

\section{Hasil Inovasidan Pembahasan}

a. Desain Pengembangan Sistem

Aplikasi

Perancangan sistem informasi manajemen skrining case manager/ MPP berbasis web dan android ini digambarkan dengan menggunakan flowchart sistem dapat dilihat seperti gambar 1.

Prosedur kerja yang dilakukan oleh sistem yang dikembangkan dapat digambarkan dengan flowchart di atas. Prosedur diawali dengan login yang dilakukan perawat maupun case manager. Perawat malakukan penginputan data pasien sesuai kasus dan kriteria skrining case manager kemudian disimpan. Data akan

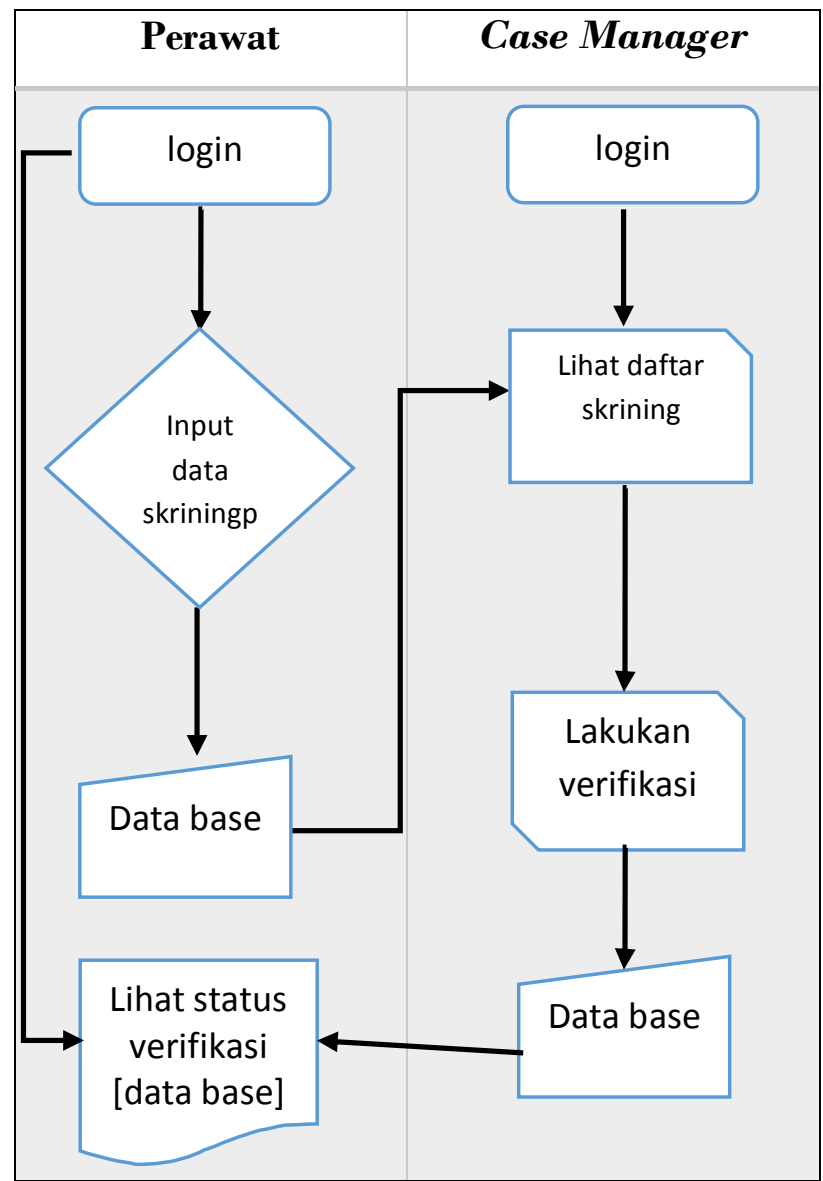

Gambar 1. Flowchart Sistem Informasi

Manajemen Skrining Case Manager

tersimpan di database dan secara real time dapat dipantau oleh case manager,

kemudian case manager melakukan verifikasi terhadap data skrining yang masuk. Setelah dilakukan verifikasi, data akan tersimpan dan secara real time akan mengganti status verifikasi hasil skrining. Tanda “!” menunjukkan data hasil skrining belum diverifikasi dan/ atau belum dibaca oleh case manager, tanda " $\sqrt{ } "$ menunjukkan data telah diverifikasi oleh case manager dan menunggu follow up selanjutnya oleh case manager di ruangan pasien. Proses update data secara real time ini mempersingkat waktu pelaporan hasil skrining pasien 
yang menggunakan telepon atau menunggu datangnya case manager tiba di ruangan.

b. Desain Antarmuka Sistem (Interface) Desain tampilan diperlukan agar dapat digunakan pengguna untuk menginput data ke dalam komputer. Tampilan antar muka ini memudahkan pengguna dalam melakukan input data. Desain yang dikembangkan mengacu pada desain Flat user interface. Flat user interface merupakan tren populer dalam desain web dan saat ini gaya desain yang dominan dalam antarmuka mobile (LaGrone, 2016). Desain Interface ini terbagi menjad 2 user utama yaitu

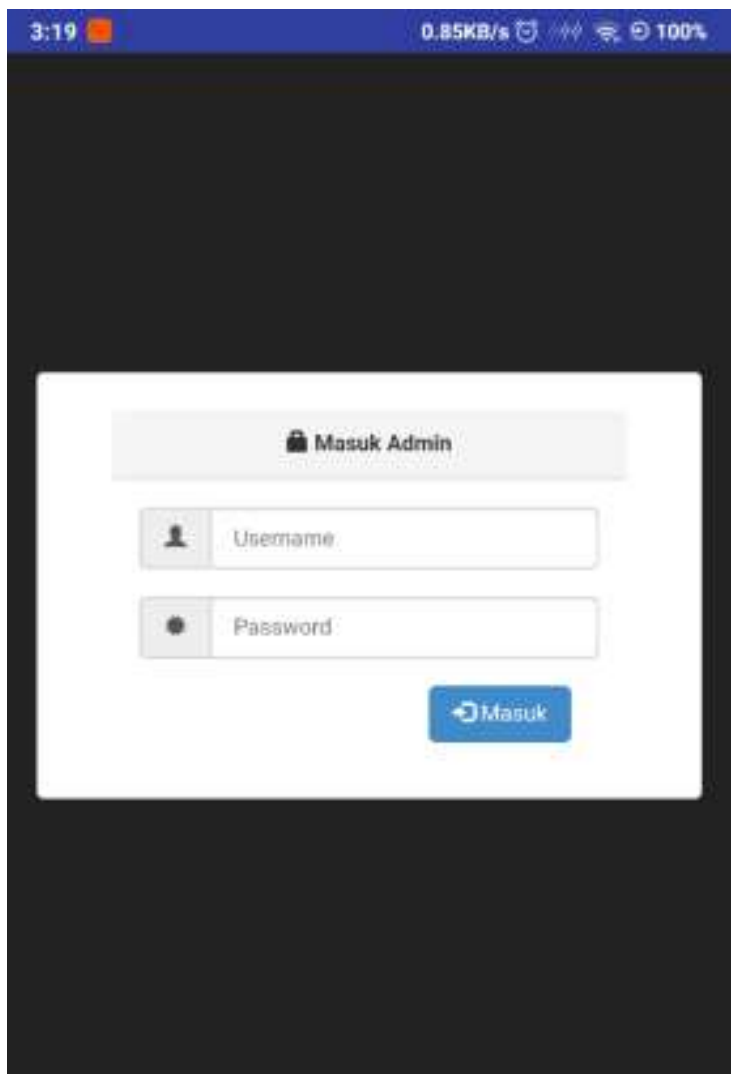

Gambar 2. Tampilan Halaman loginuser perawat dan case manager. Berikut adalah tampilan antarmuka sistem yang telah dibuat:

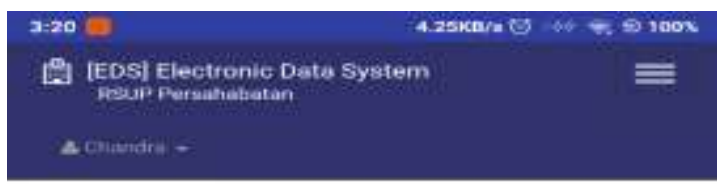

Dashboard Statistics Overview

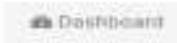

\section{Selamat datang di halaman Perawat!}

\section{Electronic Data System created by FIK UI 2018}

\section{RS PERSAHABATAN}

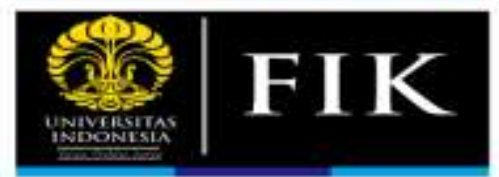

Gambar 3. Tampilan dashboarduser perawat

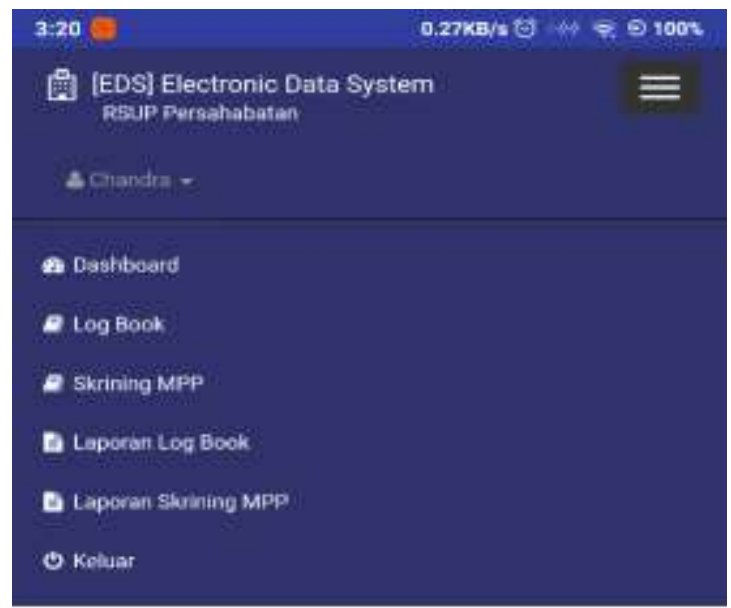
Electronic Data System
created by FIK UI 2018

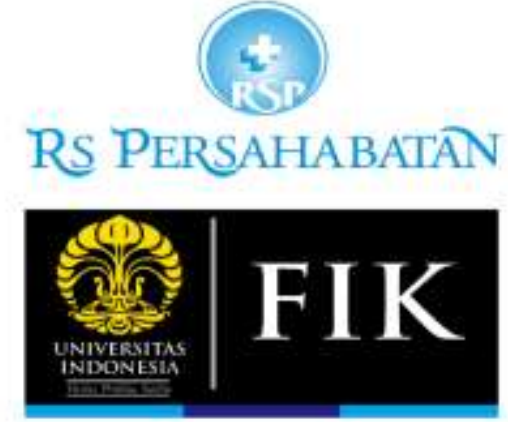

Gambar 4. Tampilan Menu user perawat 


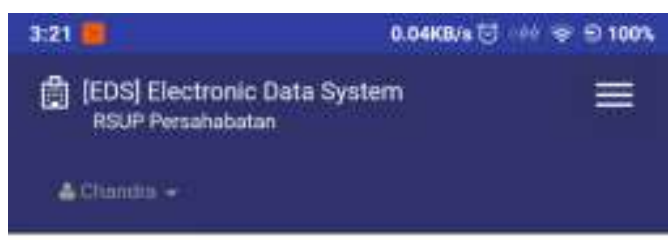

\section{Tambah Data}

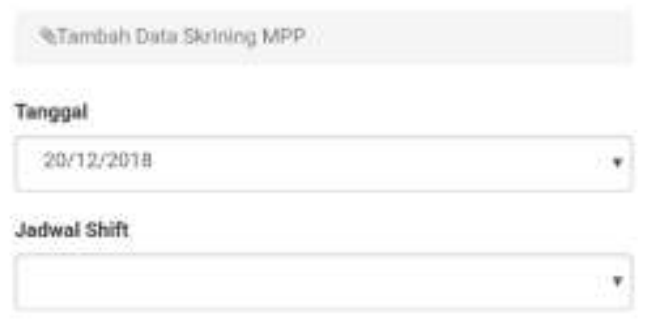

Nama/RM
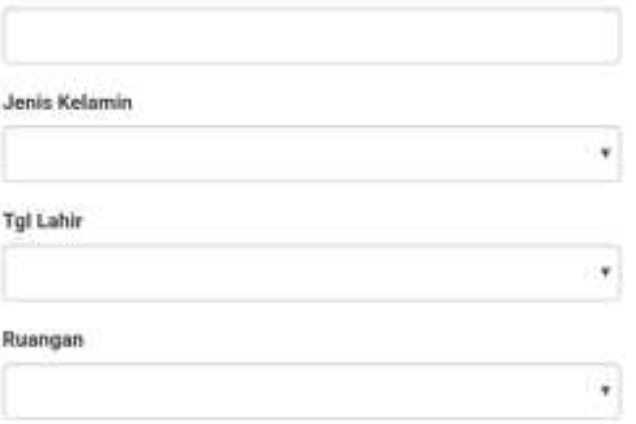

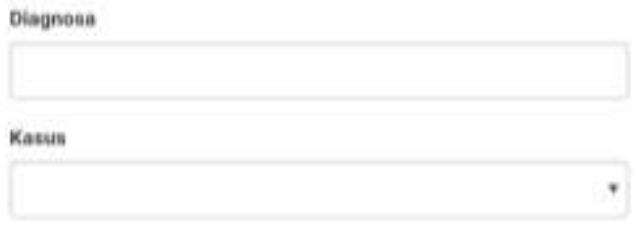

Kriterla

3 Biaya tingo

Potenaial komplarn

Kasuil derrgan Penyakit ivonis, hatastropik, terminal

Katus komipleks

Kendale watem pembayaran

Alos memariang

Membutuhikan kentinutas

\section{Almpan}

Skrining MPP

Gambar 7. Tampilan Menu skrining MPP user perawat berbasis

User melakukan login pada menu login (gambar 2) untuk melanjutkan ke halaman dashboard(gambar 3). Perawat akan masuk ke menu skrining MPP (gambar 4)dan melakukan skrining dengan mengisi biodata pasien, lalu dilanjutkan memilih kriteria skrining sesuai dengan yang tersedia di menu skrining, lalu simpan (gambar 7).

Data skrining yang tersimpan di database untuk dilakukan verifikasi oleh case manager. Case manager akan masuk melalui menu login (gambar 2), kemudian memilih menu laporan skrining MPP (gambar 4) dan melakukan verifikasi hasil skrining dengan menekan tombol verifikasi. Hasil verivikasi akan secara real time ter-update di data base dan dapat dilihat oleh perawat secara cepat melalui menu laporan skrining MPP (gambar 10). Gambar 9 menunjukkan contoh daftar hasil skrining perawat yang akan dan telah diverifikasi oleh case manager. Gambar 10 menunjukkan contoh tampilan status verifikasi hasil skrining oleh case manager yang dapat di akses oleh perawat pada menu laporan skrining MPP.

Semua proses diatas dapat terupdate secara real time. Dengan demikian hasil skrining dan status perifikasi dapat terpantau oleh case manager dan perawat dengan cepat, tanpa harus menunggu pelaporan melalui telepon atau menunggu case manager sampai di ruangan. Hal ini akan meningkatkan efektifitan dan efisiensi waktu.

c. Pengendalian Sistem

Sistem ini berada dibawah kendali unit sistem informasi rumah sakit. User utama adalah case manager (admin 3) dan karu/ katim. Case manager berada dibawah pengawasan Direktur Medik dan 


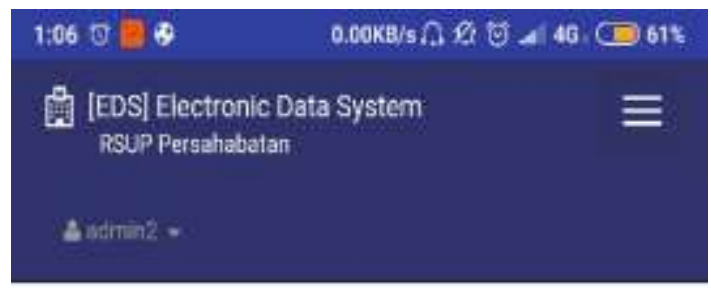

Skrining MPP

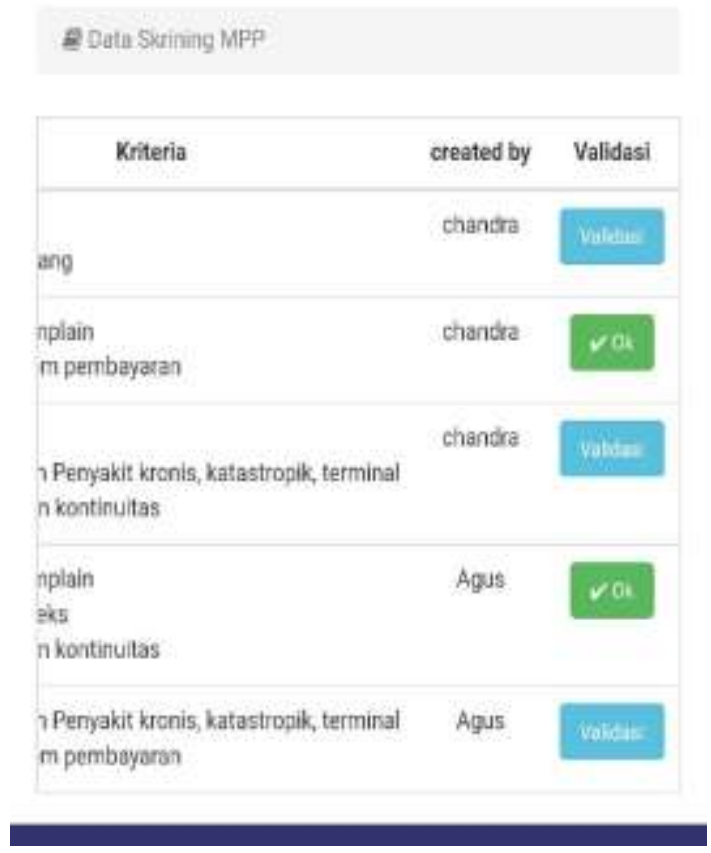

Gambar 9. Contoh tampilan verifikasi data skrining oleh case managerberbasis android

keperawatan, sehingga user yang mengawasi jalannya sistem skrining ini yaitu Direktur Medik dan Keperawatan (admin 1), Kepala Bidang Pelayanan Keperawatan (admin 2). Akun admin ini dapat digunakan untuk mengawasi bagaimana jalannya sistem ini, berapa jumlah pasien yang diskrining setiap hari dan berapa total pasien tiap bulan, sehingga dapat dilihat kesesuaian untuk laporan case manager dan juga IKI case manager. Ini merupakan salah satu fungsi pengendalian dalam manajemen (Robbins and Judge, 2017).

Perngoperasian sistem diawali dengan proses login oleh user. User terdiri dari dua, yaitu case manager sebagai admin, dan perawat yang melakukan skrining. Langkah selanjutnya yaitu membuka

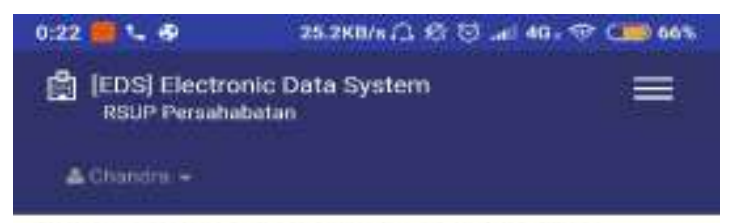

Laporan Skrining MPP

DL Leporan skrining MPP

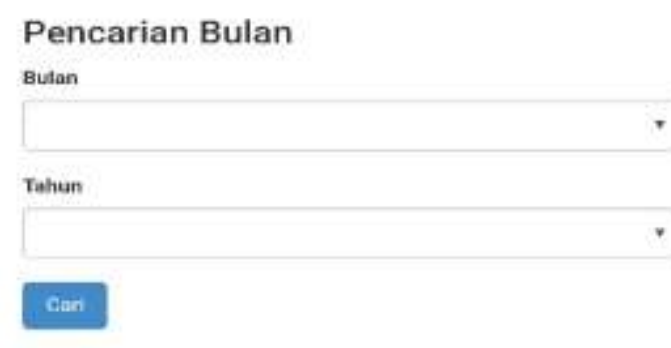

Laporan Skrining Bulan Desember Tahun 2018

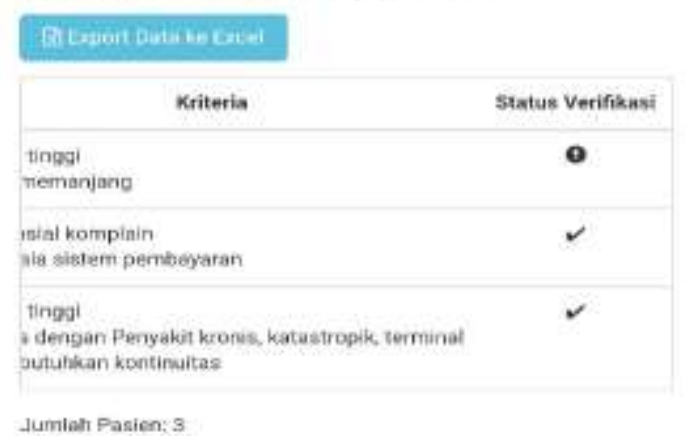

Gambar 10. Contoh tampilan status verifikasi hasil skrining berbasis android menu skrining MPP lalu mengisi data pasien beserta kriteria skrining yang sesuai. Setelah itu perawat menyimpan data yang telah diisi. Data hasil skrining yang telah tersimpan akan terupdate secara real time pada akun case manager untuk dilakukan verifikasi. Case maneger dapat melakukan verivikasi hasil skrining pada menu skrining MPP dengan menklik "validasi". Jika telah diverifikasi maka tombol "validasi" akan berubah manjadi "V OK" yang menandakan hasil skrining telah diverifikasi. Selanjutnya untuk user perawat dapat melihat status verifikasi dengan membuka menu laporan skrining MPP, memilih bulan dan tahun, kemudian klik "cari" maka akan muncul semua data pasien hasil skrining beserta status verivikasi hasil skrining. Hasil skrining yang telah diverifikasi akan menungjukkan ikon "ل/" (ceklis) 
sedangkan yang belum diverifikasi akan menunjukkan ikon “!” (tanda seru).

d. Sosialisasi

Sosialisasi rancangan dan pengoperasian sitem ini dilakukan pada tanggal 20 Desember 2018. Kegiatan ini dihadiri oleh kepala bidang keparawatan beserta stafnya, kepala instalasi dan koordinator, perwakilan komite keperawatan, serta kepala ruangan atau diwakili oleh ketua tim. Respon yang diberikan cukup positif, audiens sangat antusias dan mengapresiasi pengembangan/ inovasi yang dirancang ini. Inovasi seperti ini semakin meningkatkan pemanfaatan teknologi informasi di rumah sakit.

e. Kelebihan, Kekurangan dan Potensi Pengembangan Sistem

Prototipe ini memiliki keunggulan seperti keamanan yang menggunakan sitem akun pribadi/ user name dan password untuk masing-masing user, sehingga tidak semua orang dapat mengakses. Selain itu, sistem update yang dapat dipantau secara real time meningkatkan efisiensi waktu pelaporan hasil skrining tanpa menelepon telebih dahulu atau menunggu case manager datang ke ruangan. Data skrining dapat diekspor ke dalam format excel jika dibutuhkan. Kemudian, penggunaan kertas dapat dikurangi sehingga mengurangi biaya yang harus dikeluarkan untuk kertas dan pencetakan form manual.

Disamping keunggulan diatas, prototipe masih perlu pengembangan lebih lanjut agar dapat berjalan lebih baik dan mudah digunakan oleh user. Prototipe ini masih memiliki beberapa kekurangan yang perlu ditingkatkan dan dikembangkan seperti belum adanya fitur notifikasi khususnya di android, data pasien belum terintegrasi dengan SIMRS sehingga beberapa data seperti nama/ inisial dan nomor rekam medis, diagnosa medis masih diinput/ diketik manual, belum ada fitur pengelompokan data berdasarkan kasus, ruangan atau kriteria skrining, belum terintegrasi dengan IKI case manager.

\section{Simpulan}

Sistem skrining elektronik berbasis sistem informasi manajemen ini merupakan salah satu solusi untuk meningkatkan efisiensi dan efektifitas skrining case manager di rumah sakit. Perkembangan teknologi informasi yang cukup pesat saat ini, sehingga hampir semua orang menggunakan internet baik melalui telepon pintar atupun komputer. Hal ini menyebabkan pertukaran informasi terjadi sangat cepat sehingga lebih efektif dan efisien baik waktu, biaya dan sumber daya. Oleh kerena itu rumah sakit diharapkan dapat menerapkan sistem informasi manajemen untuk skrining case manager berbasis web dan android ini untuk mendukung proses pelayanan berjalan optimal, lebih efektif dan efisien. Hal ini untuk meningkatkan manajamen pelayanan pasien menjadi lebih baik.

\section{Daftar Pustaka}

Ben Natan, M. and Hocman, O. (2017) 'Patient-Centered Care in Healthcare and its Implementation in Nursing', International Journal of Caring Sciences, 10(1), pp. 596-600. Available at: http://www.internationaljournalofca ringsciences.org/docs/64_merav_revie w_10_1.pdf.

Ben Natan, M. and Hocman, O. (2017) 'Patient-Centered Care in Healthcare and its Implementation in Nursing', International Journal of Caring Sciences, 10(1), pp. 596-600. Available at: http://www.internationaljournalofca ringsciences.org/docs/64_merav_revie w_10_1.pdf.

Berisha-shaqiri, A. (2015) 'Management Information System and Competitive Advantage', 6(1), pp. 204-208. doi: 10.5901/mjss.2015.v6n1p204. 
CMSA (2016) Standards of prancice for case management. Revised 20. Arkansas: CMSA.

DPR RI dan Presiden (2009) UU No 44 tahun 2009 tentang Rumah Sakit.

DPR RI dan Presiden (2014) 'UndangUndang RI No.38 Tahun 2014 Tentang Keperawatan'.

JCI (2017) Joint Commission International Accreditation Standards for Hospitals. 6th edn. Oak Brook: Joint Commission International.

KARS (2017) Standar Nasional Akreditasi Rumah Sakit. 1st edn, Standar Nasional Akreditasi Rumah Sakit. 1st edn. Jakarta: Komisi Akreditasi Rumah Sakit.

LaGrone, B. (2016) Web Design Blueprints. Birmingham: Packt Publishing.

Laudon, K. C. and Laudon, J. P. (2014) Management Information Systems Managing The Digital Firm. 13th edn. Harlow: Pearson Education Limited.

Malliarou, M. Zyga, S. (2009) 'Advantages of information systems in', Smij, 5(July). doi: http:dx.doi.org/10.4127/ch.2009.0040

Menkes RI (2013) PMK No 82 Tahun 2013 Tentang Sistem Informasi Manajemen Rumah Sakit.

Robbins, S. P. and Judge, T. A. (2017) Organizational Behavior. 17th edn. England: Pearson Education Limited. 